\title{
On the Issue of the Substitution of Concepts in Determining the Subjects of the Political System of Society (Based on a Critical Analysis of Modern Legal Literature on the Theory of State and Law)
}

\section{Vladimir Valentinovich Kozhevnikov}

Department of Theory and History of State and Law, Omsk State University Dostoevsky, Omsk, Russia kta6973@rambler.ru

\begin{abstract}
This scientific article is devoted to some theoretical problems of the theory of the political system of society. The purpose of the article is to show the true, objective position in relation to the subjects of the political system. To solve this goal, the following tasks were set: a critical analysis of the opinions of those authors who consider as such: 1) criminal communities; 2) public organizations with an insignificant political aspect. Moreover, both in the first and in the second case, it has been proven that scientists are engaged in the substitution of concepts, that is, they commit a logical error. Result: 1) criminal associations are not subjects of the political system of society; 2) according to the political criterion, it is necessary to distinguish only proper political and not proper political organizations; 3) general theoretical provisions, opposite to those stated, differing in illogicality, do not contribute to improving the quality of educational literature on the theory of state and law.
\end{abstract}

Keywords

political system criminal communities, political criterion; substitution of concepts, logical error, quality of literature

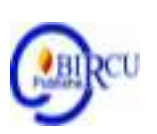

\section{Introduction}

The relevance of this topic is due to the fact that, despite the narrow (institutional) or broad approaches to understanding the political system, its participants (state, political parties, public organizations, etc.) are in any case considered components of the latter.

\section{Research Methods}

When preparing a scientific article, the following methods were used:

2.1 General Philosophical (Dialectical-Materialistic), which is used in all Social Sciences

a. general scientific (analysis and synthesis, logical and historical, comparisons, abstractions, etc.), which are used not only by the theory of state and law, but also by other social sciences;

b. special methods (philological, cybernetic, psychological, etc.), developed by special sciences and widely used for the knowledge of state and legal phenomena;

c. private scientific (formal legal, interpretation of law, etc.), which are developed by the theory of state and law. 
Konfrontasi Journal: Culture, Economy and Social Changes, 7 (3) September 2020, 228-236

ISSN: 1410-881X (Print), 2716-2095 (Online)

Vladimir Valentinovich Kozhevnikov: On the Issue of the Substitution of Concepts in Determining the Subjects of the Political System of Society (Based on a Critical Analysis of Modern Legal Literature on the Theory of State and Law) DOI: https://doi.org/10.33258/konfrontasi2.v7i3.118

http://www.konfrontasi.net/index.php/konfrontasi2

\subsection{The Concept of the Political System of Society and Its Functions}

When considering issues related to the political system, it is necessary to rely on a civilized, democratic idea of self-government, the main content of which is to ensure the real, practical participation of an increasing mass of the population in the management, development, discussion, adoption and implementation of socio-economic decisions.

The political system of society is connected with a special sphere of activity of peoplepolitics, which reflects the area of relations between classes, social groups, collectives, individuals about state power.

There are mutual links between the political system of society and its economic basis: the totality of production relations constitutes the economic structure of society, the real basis on which the political and legal superstructure rises. Considering the political system, it should be emphasized that it is based on political relations, policies that are formed in a stateorganized society in the appropriate forms. The political system is the universal governing system of a state-organized society, whose components are linked by political relations and which ultimately regulates the production and distribution of social goods based on the use of state power by large social communities.

It seems that the question of its functions is important for the characterization of the political system. Based on the fact that the political system is designed to ensure the stability of society, its progress through the balance of various group interests, we can determine the following functions of the modern political system:

- defining the goals, objectives and ways of development of the society;

- organization of the company's activities to implement the adopted goals and programs;

- distribution of material and spiritual values.;

- coordination of various interests of the state and social communities;

- formation of political consciousness, involvement of members of society in political participation and activities;

- development of rules and laws of behavior of people and groups in society;

- ensuring internal and external security and stability of the political system;

- monitoring compliance with laws and regulations, the suppression of the actions breaking political norms.

The political system of society is considered both in a narrow and broad sense. In a narrow sense, a political system (or political organization) is a set of state and non - state (public) organizations (institutions) that participate in the state and socio-political life of a country. In other words, the political system is formed by various institutions of struggle for power, for its retention, use, organization and functioning; this is a system of interconnected and interacting associations (organizations) of people based on various forms of ownership, reflecting the interests and will of social classes, strata, groups and Nations that exercise political power or fight for its existence within the framework of law through the state. It is power and its relations that characterize the political functions of various social institutions and are the system-forming factors that shape the political system. Political organization determines the structure and interrelation of political institutions and institutions, i.e. it mainly provides an institutional characterization of the political system. The main content of a political organization is a set of state and public organizations that make up the institutional and organizational structure of its political life. Political organization is the most essential element of the political system, since it is through political organizations that the main goals and objectives of society are put forward and the political line is defined, political and legal norms are formed, and the entire society is mobilized. Political organizations are connected to each other in a certain way, interact with each other in one way or another, and in their unity 
form a certain system with all its inherent characteristics: competence, integration, organization, etc.

In a broad sense, the political system is understood as a system of state and non-state public institutions, social norms, including legal ones, through which political and power relations are implemented. In other words, in a broad sense, the political system is considered as a complex complex of political relations, political consciousness, political and legal norms, state institutions, political parties, public organizations, within which the political life of society takes place, state power and management are carried out.

In this case, the political system is a dialectical unity of the following parties:

1. Institutional (or organizational) (state, political parties, other public organizations).

2. Regulatory (or normative) (law, political relations, political norms and traditions, some moral norms).

3. Functional (methods of political activity that form the basis of the political regime).

4. Ideological (political consciousness, including political ideology and political psychology, and political culture).

The institutional side of the political system is represented by organizations that are somehow connected with politics. This is the main, Central component of the political system of society, in which, in fact, the political system is externally represented. These include elements such as the state, political parties, and other public associations whose activities are directly or indirectly related to politics. These elements act as subjects of the political system, which will be analyzed below

Within the framework of the regulatory side of the political system, it is necessary to highlight its regulatory framework, which acts as the most important form of regulating political relations, ensuring a certain level of social organization, stability and stability of both political institutions and the entire political system as a whole. The normative system of the political system consists of a variety of social norms: legal norms, norms of public organizations (statutory), party decisions, political traditions and customs, moral norms, etc. The subject of regulation of the components of the normative framework is political relations that arise in the political system either in the process of direct exercise of political power, or about it. Therefore, the political aspect of the content of principles and norms should be one of the most important criteria for their "inclusion" in the normative framework.

Bearing in mind that the normative basis of the political system of society is: 1) legal principles and norms that have a political content; 2) principles and norms contained in the acts of party bodies and public organizations; 3) political traditions; 4) political customs; 5) principles and norms of morality (morals), we will describe them in more detail.

Legal principles and rules of a political nature. In legal form take on a variety of relationships between elements of political system that are implemented in various spheres of interrelation and interaction of the state with other elements-integral parts of the political system legislated in all countries secured political and legal framework political system, which enshrines the various formal and substantive principles of its existence and functioning: the sovereignty of the people, democracy, pluralism, legality and constitutionality. The most important acts of the normative basis of the political system are constitutions, which reflect and consolidate not only the legal basis of the political system, but also its economic, spiritual and political system.

The norms of law contained in constitutions and other legal acts are very important, but not exhaustive, components of the normative basis of the political system, because the law cannot regulate all political relations in society. It has its limits. The law cannot, for example, 
regulate intra-party and other similar relations. For this reason, the mechanism of social regulation of political relations is supplemented by other social principles and norms (morals, principles and norms contained in the acts of party bodies and public organizations; traditions and customs). But this does not mean that other social principles and norms cannot regulate the same relations as the law. The operation of these non-legal principles and norms may be complementary to the law. The very fact of mixed regulation of various relations that arise between elements of the political system gives reason to speak about the consistency of their actions, the flexibility and order of the process of regulating political processes.

The principles and norms contained in the acts of party bodies and public organizations regulate relations between party and public organizations, parties and the state, the state and public organizations. These rules can be divided into "internal" and "external" actions. Political norms of "external" action contained in the charters, programs, and other acts of public organizations can be both recommendatory (expressed, as a rule, in the form of proposals and wishes that are not binding) and imperative (they are to some extent inherent in such features and features as the authority and General obligation of the instructions contained in them). he political norms contained in the statutes and other acts of public organizations are of great importance: with their help, formal unity, the integrity of a public organization is created, the creation of a single power in it is recorded.

Political traditions and customs have such common features as continuity, relative stability, emotionality. In the field of political relations, there are many customs and traditions of mutual communication between groups of people, classes, state and public organizations: the existence of political opposition, the presence of a multi-party system, the construction of a state mechanism based on the principle of separation of powers, etc.

For political traditions and customs, the presence of visual-emotional means of their accompaniment is characteristic, which give them greater expressiveness and effectiveness of their action as regulators. Political traditions and customs contribute to the stabilization of social relations, an increase in the level of ordering of society, and the progressive development of the political system. One of the features of political traditions and political customs is their close connection with the state, with political life. This connection is due to the fact that the essence of the policy of the state, which is interested in their development, consolidation, giving them a legal character in certain periods, often finds expression in political traditions and custom, or vice versa. In some cases, traditions and customs are combined with the norms of law: the law either authorizes them, or rejects them, or is silent. Political traditions and customs are not limited to any narrow sphere of political life or any part of the political system: they operate in almost all areas of the exercise of political power. So, political customs act as concretized norms of behavior of various organizations, structural elements of the political system in the field of relations regarding the conduct of election campaigns, the elections themselves. This is explained by the fact that they are formed on the basis of actual political relations, due to their repeated repetition. Their existence is also due to the fact that customs act as a kind of means of organizing the execution of a legal norm, combining and intertwining with it.

Traditions, however, encompass the main, essential political relations. They do not provide for a detailed regulation of social relations, like customs.

The sphere of activity of political traditions and customs is the circle of relations associated with the exercise of state power, with the formation of representative bodies - state and public, exercising public control over their activities with the realization of the rights and freedoms of citizens. 
In the normative basis of the political system of society, a special place is occupied by the norms of morality (morality). By placing higher demands on the participants in relations than other social norms, they thereby impose additional responsibilities on the subjects of political relations. The principles and norms of morality reflect the main social obligations, as well as the awareness of the individual of his social significance.

For the normative basis of the political system, it is important that political norms are based on the norms and principles of universal human morality, which would permeate their content and determine their features. The penetration of morality into politics means that they must form a single moral and political basis for social management. However, in the practical political life of modern states, such penetration does not always happen: morality often diverges not only from politics, but also from law.

As for the ideological component of the political system, then, as noted above, we are talking about political consciousness and political culture. Moreover, political consciousness is considered from the point of view of the following structure: 1) political ideology is a system of ideas, views, concepts on political life, ways of explaining the world of politics, which is based on values, orientations towards certain political phenomena, processes, structures; 2) political psychology - a set of feelings, emotions, psychological stereotypes, reflecting people's attitude to the current political system of society, politics, political institutions.

Political culture is a system of norms of political behavior prevailing in society based on ideas about political ideals, a just state, the meaning of political life, the significance of political struggle, ways of assessing and explaining political phenomena.

\subsection{Criteria for the Subjects of the Political System of Society}

In our opinion, it is logically and methodologically justified that first, regardless of the classification of the subjects of the political system of society, certain criteria (features) are analyzed that allow one or another organization to be attributed to the subjects (institutions) of the political system. In the legal literature, the following are called as such.

The organizational criterion boils down to the fact that each subject, is considered, acts as a structural element, as an organization, the characteristic features of which are a certain order of its formation and functioning; the existence of a charter, regulation or other act indicating the formation of a particular association; the presence of bodies leading their internal and external affairs.

Political criterion means the ability of an organization, first, to express the political interests of a class, group, or other social community; secondly, to be a participant in political life and bearer of political relations; thirdly, to have a direct or indirect relationship to state power, its conquest, organization or use, and not necessarily in the form of interaction with state bodies, but also counteraction to them; fourthly, to be guided in their daily activities by political norms or rules prevailing in the political life of this or that country [1].

The program criterion is expressed in the normative consolidation (in charters, regulations, programs) of the political orientation of the organization's activities, reflecting the purpose of creating a political organization, its social purpose, the main field of activity, the nature of its main tasks and functions, the peculiarities of their implementation, specific principles of organization and activities, and etc. The program criterion allows you to determine the degree of participation of an organization in political life country, to fix its political goals and objectives, that is, inclusion in the political system of society. 


\subsection{Legality as a Criterion for the Subjects of the Political System}

It seems that in order to immediately reject the position of scientists who consider criminal communities to be subjects of the political system, one should also take into account such a criterion as legality, bearing in mind that the state, political parties, and other organizations must carry out their activities on a legal basis. In other words, the point is that the functioning of the political system is based on legal norms; all its organizational structures must operate within the framework and on the basis of laws that form the legal basis of state and public life.

\section{a. Supporters of the Recognition of Criminal Communities as Subjects of the Political System}

Nevertheless, emphasizing that not all scientists share this approach, some authors admit that some criminal communities, possessing significant financial resources, contribute to corruption, put pressure (here and hereinafter we have highlighted - Vladimir Valentinovich Kozhevnikov) on the bodies of not only the executive, but also the judicial system. Scientists who recognize criminal communities as subjects of the political system write that "it should be assumed that, in the absence of a fight against corruption, some officials of government bodies closely associated with it will make decisions that will benefit not the entire civil society, but a narrow the circle of persons included in organized criminal communities "[2].

Nikolai Aleksandrovich Vlasenko adheres to a similar position, arguing that "the direct impact of criminal communities on political and legal processes in society testifies in favor of their recognition as an independent component of the political system of the Russian Federation" [3]. Vladimir Mikhailovich Syrykh is convinced that subjects prohibited by law are institutional components of the political system. Arguing his position, the scientist writes the following: "A political organization (as the author called the political system - Vladimir Valentinovich Kozhevnikov) of a civil society can consist not only of organizations and associations authorized and recognized by the state. It may contain associations of a fascist, extremist persuasion, other parties, movements, the activities of which the state finds dangerous for itself and the interests of a certain social stratum, class or society as a whole protected by it. In modern conditions, the political life of the country, activities state bodies, officials, criminal communities can seriously influence ... ", which," having a significant fortune ... bribe government officials, take their representatives to the legislature and try to put pressure on the executive authorities "[4].

\section{b. Opponents of Recognizing Banned Organizations as Subjects of the Political System}

It should be noted that not all authors really adhere to this position. Thus, Lyudmila Aleksandrovna Morozova and other scientists argue that banned (criminal) communities and associations "have no right to officially participate in the political life of the country. They are outside the law, their activities are illegal, although, of course, they are trying to occupy a certain place in the political life of the country " $[5 ; 6]$.

It seems that, firstly, the argumentation of the supporters of the inclusion of criminal organizations does not stand up to criticism at all, because, firstly, they, not being subjects of the political system, can only exert influence, pressure on official state structures and their officials. In other words, in this case, criminal communities act as one of the external factors influencing the political system of society. 


\section{Discussion}

\subsection{Substitution of Concepts, Or a Logical Error}

Secondly, in this case, there is a substitution of concepts, that is, a logical error consisting in the issuance of an object (or phenomenon) as such, which it obviously is not, and in the use of a word definition that does not correspond to the context. In the context of this article, we are talking about the unjustified giving the status of a subject of the political system to criminal communities that are not. In this case, it seems, there is a violation of the rules and laws of formal logic, which, along with other criteria (legal practice, language rules and methodological rules) act as a criterion for the truth of knowledge about the state and the law [7].

If we develop our point of view more specifically, then we are talking about such a logical error as paralogism (from the Greek paralogismos-near, near logic), that is, an unintentional logical error resulting from an insufficiently high culture of thinking: in the ambiguity of the formulation of thoughts, in inconsistency and groundlessness in reasoning. In the philosophical dictionary, paralogism is associated with wrong reasoning, unintentional violation of the laws and rules of logic, depriving reasoning of probative power and usually leading to false conclusions [8].

\subsection{Classification of the Subjects of the Political System by Political Criterion}

Another example of paralogism, again within the framework of the theory of the political system, is associated with one of the classifications of the subjects of the political system. Without diminishing the importance of other criteria, scientists emphasize that the second (political) criterion is of particular importance, on the basis of which all subjects of the political system are divided into the following types:

a. proper political organizations - the state, all political parties, some public organizations. Their characteristic feature is a direct, direct connection with politics: the task of their creation and functioning is to achieve a certain political goal, which is enshrined in statutes and programs and consists in carrying out various political events;

b. not actually political organizations that arise and develop due to economic and other nonpolitical reasons. These are trade union, cooperative and other organizations that carry out their activities in the production, social, cultural and other spheres of society, and they do not fix political goals in their statutes. However, this does not mean belittling the role and importance of these organizations in the political system of society. It is only about the absence of a dominant political aspect in their activities, and not about the denial of this as such;

c. organizations that have an insignificant political aspect in their activities. These include associations that arise and function on the basis of personal inclinations and interests of people to engage in certain activities: societies of philatelists, tourists, car enthusiasts, etc. Scientists argue that they acquire a political connotation only as a result of the influence of government and other political organizations [9].

Other authors also call this group of subjects as "organizations that do not have a completely political aspect" [10], or designate them as "minor political organizations" that are not "... subjects of political power, but objects of state influence and other political organizations "[11], act" ... not as subjects-carriers of political power and corresponding political ideas "[12] 
This example of a logical error is quite paradoxical: on the one hand, while calling the corresponding organizations the subjects of the political system, they are unreasonably identified with the objects of influence of the state and other political organizations; on the other hand, first recognizing that the respective organizations meet the political criterion, they are further characterized as "organizations in which there is no political dimension at all".

It seems that a more reasoned position on the problem under consideration is the point of view of Oleg Yuryevich Vinnichenko and Vladimir Ivanovich Popov, who argue that "non-governmental organizations performing political functions are divided into two large groups: political organizations proper, aiming to conquer, retain and use state power; organizations participating in political life insofar as it is related to their main goals and objectives (trade unions, environmental, religious organizations, etc.) "'[13].

\subsection{Discussion}

The main controversial issues in the context of this article are: 1) recognition or, conversely, non-recognition of criminal communities as subjects of the political system of society; 2) the subject of the political system or the object of influence of state and other political organizations, public organizations that have an insignificant political aspect.

\section{Conclusion}

In this part of this study, it should be emphasized that the above examples relating to certain aspects of the political system of society, which are illogical, firstly, do not contribute to the achievement of the truth of political and legal problems; secondly, they negatively affect the quality of textbooks on the theory of state and law - the most important legal science that has a methodological nature in relation to other legal sciences, which is the basis of the fundamental education of modern lawyers.

Recommendations: We believe that academic theorists who analyze the institutional aspect of the political system must comply with the rules and laws of formal logic.

\section{References}

[1] Abdulaev Magomet Imranovich, Komarov Sergey Alexandrovich. Problems of the theory of state and law: textbook. Saint Petersburg: Peter, 2003, p. 143.

[2] Problems of the theory of state and law: textbook / ed. Vladimir Mikhailovich Syrykh M .: Eksmo, 2008, pp. 142 .

[3] Vlasenko Nikolai Alexandrovich. Theory of state and law: textbook. Moscow: Prospect, 2015, p. 94.

[4] Syrykh Vladimir Mikhailovich. Theory of state and law: textbook. Moscow: Justicinform, 2005, p. 496-497.

[5] Morozova Lyudmila Alexandrovna. Theory of state and law: textbook. Moscow: Eksmo, 2007, p. 138.

[6] Rybakov Vladimir Alekseevich. Problems of the theory of state and law: a course of lectures. Omsk: Omsk region. University, 2010.S. 280

[7] Kozhevnikov Vladimir Valentinovich. On the question of the criteria for the truth of knowledge about the state and law // Modern Law. 2010. \# 12. S. 12-16.

[8] Philosophical Dictionary / Ed. Ivan Timofeevich Frolov. M .: Politizdat, 1986.S. 355. 
[9] Pyanov Nikolai Andreevich. Consulting on the theory of the state: a textbook. Irkutsk: Irkutsk region. Univ., 2010.S. 261.

[10] Radko Timofey Nikolaevich. Theory of state and law: textbook. M .: Academic project, 2005, p. 229.

[11] Rybakov Vladimir Alekseevich. Decree. op. P.270

[12] Boshno Svetlana Vladimirovna. Theory of state and law: textbook. M .: Eksmo, 2007.S. 351.

[13] Vinnichenko Oleg Yurievich, Popov Vladimir Ivanovich. Theory of state and law: textbook. M .: Prospect, 2010. 184. 